\section{FISHERIES \\ Prediction of Selection Factors in a Tropical Trawl Fishery}

THE discovery of a potential trawl fishery in an under-developed region may lead to the rapid expansion of the mechanized fleet and the exhaustion of the resource in a very few years; this has recently occurred in Liberia ${ }^{1}$ and appears to be happening in Ghana $^{2}$. If it were possible, in the early stages of development, to introduce appropriate mesh-size regulations (together with a vessel-licensing system) the exploitation of the resources might be placed on a more rational basis ; but it is characteristic of such a situation both that the research facilities are limited and that the exploited stocks comprise a variety of species, each of which will be selected differently by a particular mesh-size. Devold ${ }^{3}$ comments on such a situation, which has now arisen through the introduction of modern trawlers on the Brazilian coast.

As an interim measure, and as an alternative to legislation by intuition, the derivation of selection factors $(S)$ from the length/girth $(L / G)$ relationship appears to be promising. Graham ${ }^{4}$ commends such a derivation, but the relationship between $L / G$ and $S$ appears to have been little investigated; Margetts ${ }^{5}$ has made an indirect approach in the case of European haddock and whiting, while Cassie ${ }^{6}$ has made a direct comparison for the New Zealand snapper. Cassie postulated that the 50 per cent retention length $\left(L^{\prime}\right)$ for snapper would be close to the length appropriate to a girth equal to the circumference $(2 M)$ of the mesh under consideration; for this species the calculated, or predicted, value of $S$ was $2 \cdot 35$, the best experimental estimate $2 \cdot 32$, the mean experimental estimate for single twine cod-ends $2 \cdot 35$. Agreement was thus much closer than in the case of Margetts's work, which was based on much more sensitive girth measurements and calculations, but where the best estimate of $S$ for haddock was $4 \cdot 06$, against the value currently accepted by the Inter. national Council for the Exploration of the Sea of $3 \cdot 30$.

For Cassies's postulate to be generally true it must be possible for a normally active fish seeking to escape from a trawl net to expand the diamond shape of the mesh nearly to its maximum area ; an experiment in which a trawl net was anchored at the surface in a 2-3 knot tideway has shown that the force necessary to thrust a greased wooden cone through the mesh to its full expansion is surprisingly small-a sudden thrust of $2 \mathrm{kgm}$. would appear to be within the powers of an active 10-12 in. teleost, and expands the mesh (in this case of single cotton twine) to within 7 per cent of the maximum possible without pulling the knots.

The $L / G$ ratios of the more important demersal fish off Sierra Leone have been investigated and it is now possible to draw up a table of predicted values of $S$ for these fish, based on the calculation $S=L^{\prime} / M, L^{\prime}$ being derived either from the equation $L=n G \pm k$ obtained by least squares in the case of good samples, or $L=n G$ in the case of small samples. These values are given in Table 1.

Concurrently with this investigation, covered cod-end experiments have been started using an open 28-ft. trawler; these will presumably require several years for completion, but preliminary data make possible an estimate of the accuracy of the predictions for two species. In the case of gwangwa the agreement between the two values is very close

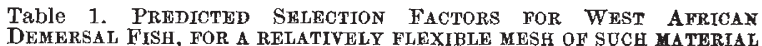
AS COTTON, MANILA OR NYLON.

Sheephead (Drepane africana)
Spadefish (Ephippus lippei)
Catfish (Tachysurus gambensis)
Snapper (Pagrus ehrenbergi)
Crocus (Pristipoma jubelini)
Shinenose (Galeoides deca !act,llus)
Gwangwa (Pseudotolithus elongatus)
Ladyfish (Pseudotolithus senegalensis)
Whiting (Pseudotolithus senegalla)
Spanish (Polydactylus quadrifilis)
Tenny (Elops senegalensis)
Ladyfish (Pseudotolithus macrognathus)
Sole (Cynoglossis goreensis)

$1 \cdot 41$
$1 \cdot 44$
$1 \cdot 91$
$2 \cdot 49$
$2 \cdot 89$
$3 \cdot 30$
$3 \cdot 58$
$3 \cdot 66$
$3 \cdot 71$
$3 \cdot 92$
$4 \cdot 22$
$4 \cdot 26$
$4 \cdot 56$

('Table 2) but in the case of crocus (etym. 'croakers', Creole?) the experimental value of 3.45 for a small sample of 338 fish is not very close to the predictionthough even so the value of $L^{\prime}$ for the mesh used is within 5 per cent of that predicted $(\mathbf{1 9 . 5}$ against $21.3 \mathrm{~cm}$.$) .$

Table 2. Predicted and Experimental Retention Data

\begin{tabular}{|c|c|c|c|c|c|c|c|}
\hline & \multirow[t]{2}{*}{ PRED } & \multicolumn{3}{|c|}{$\begin{array}{l}\text { ED AND EXPERIMEN } \\
\text { FOR GWANGWA. }\end{array}$} & \multicolumn{3}{|c|}{$L^{\prime}$} \\
\hline & & $N$ & $M$ & $S$ & $0 \%$ & $50 \%$ & $100 \%$ \\
\hline Series $\boldsymbol{A}$ & $\begin{array}{l}\text { Exp. } \\
\text { Pred. }\end{array}$ & 2738 & $6 \cdot 70$ & $\begin{array}{l}3.47 \\
3.48\end{array}$ & $\begin{array}{c}(13 \cdot 0) \\
13 \cdot 0\end{array}$ & $\begin{array}{l}23 \cdot 25 \\
23 \cdot 33\end{array}$ & $\begin{array}{l}27 \cdot 0 \\
31 \cdot 49\end{array}$ \\
\hline Series $B$ & $\begin{array}{l}\text { Exp. } \\
\text { Pred. }\end{array}$ & 2076 & $6 \cdot 79$ & $\begin{array}{l}3 \cdot 49 \\
3 \cdot 47\end{array}$ & $\begin{array}{l}(12 \cdot 0) \\
13 \cdot 23\end{array}$ & $\begin{array}{l}23 \cdot 75 \\
23 \cdot 61\end{array}$ & $\begin{array}{l}28 \cdot 0 \\
31 \cdot 87\end{array}$ \\
\hline
\end{tabular}

Series $A, 10$ hauls; series $B, 16$ hauls, totalling together $40 \frac{1}{4} \mathrm{hr}$. trawling time in the Sierra Leone estuary. $N$, number of fish in each series, $M$, mesh in cm., $L^{\prime}$, percentage retention length in $\mathrm{cm}$.

The disparity between the predicted values for gwangwa in Tables 1 and 2 arises from the fact that over the size range of fish examined the slope of $L / G$ has a significant positive intercept-so that the value of $S$ will vary slightly with the mesh size. Table 1 is based on mean figures for 1-, 2-, 3- and 4-in. meshes and Table 2 on 6.70- and 6.79-cm.meshes.

An attempt has also been made to predict the range of the selection ogive ; but here the agreement between prediction and experiment in the same two species was rather poor (Table 2). A survey was made of all available published selection ogives, from which a mean value for the range $(R)$ in terms of the ratio $R / L^{\prime}$ was obtained- 0.79 for roundfish, 0.53 for flatfish. These were further broken down into $R_{1}$ (the range $0-50$ per cent retention) and $R_{2}(50-100$ per cent); a mean for roundfish was calculated-$R_{1}=0.53 R, R_{2}=0.44 R$. For gwangwa, the selection in fact proved to be much sharper for $R_{2}$ than was predicted, and was in the region of $0 \cdot 26 R$, while the inclusion in the cod-end of many very small fish stunned by the large and prevalent scyphomedusæ of these waters extended the ogive to the lower limit of the size-frequency distribution of the sample.

The great range in the values of $S$ for these fish reflects the diversity of the commercial species and indicates the difficulty of reaching rational exploitation of such stocks; but it is hoped that it will be possible to use these predictions to determine, to some extent, the effect of mesh size in the now rapidly expanding Sierra Leone trawl fishery in which, subjectively, the size and fishing power of the fleet appears to be approaching the limit which the resources will stand.

Fisheries Development and Research Unit,

Axan R. Longhurst Freetown, Sierra Leone. July 7.

' Miller, G. C., U.S. Dept. Interior, Fisheries Leaflet, 440 (1957). Johnson, F. R., Rep. Fisheries Department, Ghana, 1957 (1958). Devold, F., Rep. Govt. Brazil on Fishery Biology. F.A.O. Rpt. 798 (1958)

- Graham, M., J. Conseil, 20 (1), 64 (1954).

- Massie, R. M., N.Z. Marine Dept. Fisheries Bulletin, 11 (1955). 